\title{
FINANČNÍ ŘíZENÍ STAVEBNÍHO PODNIKU
}

\section{FINANCIAL MANAGEMENT OF THE CONSTRUCTION COMPANY}

\author{
Karolína Antošová ${ }^{1}$ \\ ${ }^{1}$ University of West Bohemia, Faculty of Law, Univerzitni 8, 30100 Pilsen, Czech Republic
}

\begin{abstract}
Abstrakt - CZ
Tato práce je věnována tématu finančního řízení stavebního podniku. Práce se věnuje problematice řízení, jeho úkolům, cílům, závislostem na velikost stavebního podniku a vývoji stavební produkce a rovněž přibližuje rizika vyskytující se ve stavebnictví. Dále je představen controlling a reporting ve stavebním podniku Metrostav a.s. a prostředky a nástroje, jimiž je $v$ této společnosti řízeno finanční hospodaření.
\end{abstract}

\section{Klíčová slova - CZ}

Finanční řízení, finanční analýza, poměrová analýza, horizontální analýza, vertikální analýza, controlling, checklist, rozvaha, výkaz zisku a ztrát.

\section{Abstract - EN}

This paper informs about the financial management in the construction company. The work describes problems of the management, its tasks, goals, dependencies on the size of the construction company and progress in the construction production and also introduce topic of the risks in the construction business. Also controlling and reporting in the construction company together with basic tools are described in example of Metrostav a.s. in this work.

\section{Keywords - EN}

Financial management, financial analysis, financial ratio analysis, horizontal analysis, vertical analysis, controlling, checklist, balance sheet, statement of income.

\section{JEL Classification}

M40, G10, L74

DOI: https://doi.org/10.14311/bit.2016.02.06

Editorial information: journal Business \& IT, ISSN 2570-7434, CreativeCommons license (c) (i) published by CTU in Prague, 2016, http://bit.fsv.cvut.cz/ 


\section{1. Úvod}

Stejně jako chemie, fyzika nebo biologie je i samotná ekonomie vědou, bez které se v dnešní době nelze obejít. Snad ještě více než jmenované tři přírodní vědy ovlivňuje každodenní život běžného občana. Proto je velmi vhodné její problematice porozumět. Z pohledu finančního manažera nejenom stavebního podniku se porozumění této problematiky rovná, s trochou nadsázky, otázce života a smrti společnosti.

Právě v případě stavebnictví je ekonomie, potažmo finanční rízení, stěžejní disciplínou z hlediska schopnosti podniku udržet si konkurenceschopnost a generovat zisk. Dalším aspektem ovlivňující finance ve stavebním podniku je specifičnost celého odvětví, na které nejdou zcela uplatnit postupy užívané ve výrobním nebo průmyslovém podniku.

Právě v okruhu finančního řízení stavebního podniku se rozhoduje o jeho úspěšnosti, stanovují se jeho cíle a následně se kontroluje jejich plnění. A to i za pomoci vědeckých disciplín, již může být např́iklad i finanční analýza, díky které zjistíme množství potřebných informací o kondici podniku.

Finanční analýza je tedy jedním z prostředků pro řízení podniku, její použití je ale vzhledem $\mathrm{k}$ účetním závěrkám z velké části možné až retrospektivně po zaúčtování nákladů. Proto se podniky musí uchýlit $\mathrm{k}$ jiným nástrojům, jak řídit svoji rentabilitu, likviditu atp. Právě tyto nástroje budou představeny $v$ další ćásti této práce na př́kladu stavební firmy Metrostav a.s.

\section{Význam finančního ř́zení podniku}

Finanční řizení je jedním ze základních nástrojů, jak zajistit finanční zdraví podniku. Tím můžeme rozumět jednak snahu generovat zisk, zvyšovat hodnotu podniku, nebo zkrátka přežít neočekávanou situaci na stavebním či jiném trhu.

Finanční řizení čili management musí jít nicméně ruku v ruce $s$ dalšími řídícími činnostmi podniku. Oproti ostatním činnostem se vyznačuje výrazně integrujícím a průřezovým charakterem. Finanční ředitel respektive oddělení si nesmí hrát na svém vlastním písečku a musí být $v$ kontaktu $\mathrm{s}$ obchodním, technologickým či prípadně dalším oddělením v závislosti na velikosti podniku. Právě velikost podniku je určující i pro velikost a strukturu finančního oddělení firmy.

\section{1 Úkoly finančního řízení}

Finanční řizení podniku má kromě spousty podpůrných především čtyři základní úkoly (1):

- opatřovat kapitál. Jsou to aktivity týkající se pasiv. Jedná se o zajištování financování, restrukturalizování zdrojů, vydávání akcií či obligací atp.,

- rozhodovat o umístění kapitálu. Tyto aktivity se týkají především strany aktiv jako napríklad nákup majetku, financování běžné činnosti,

- rozhodovat o rozdělení zisku. Zda se zisk vyplatí formou dividend, nebo se reinvestuje formou nerozděleného zisku do dalších aktivit podniku,

- zajištovat finanční stabilitu. Řídit hospodaření podniku tak, aby byla zajištěna jeho solventnost a likvidita.

K tomu, aby všechny tyto úkoly byly smysluplně uskutečňovány a naplňovány, je nutné mít $v$ podniku kvalitní management. Jak již bylo řečeno výše, jeho struktura záleží především na velikosti podniku. 


\section{2 Řízení v závislosti na velikosti podniku}

Nejenom u stavebních podniků se struktura společnosti řídí jednak její velikostí, tak i právní formou podnikání.

\subsubsection{Malé a střední podniky}

Řízení malých firem není zákonitě tak náročné jako správa velkých obchodních společností $\mathrm{s}$ několika divizemi čítající nespočet další oddělení. $V$ malých podnicích zastává roli finančního ředitele zpravidla majitel podniku, či pověřený hospodář nebo pokladník.

Majitel podniku je tak $v$ mnohem těsnějším vztahu se svým majetkem, než je akcionář spojen $\mathrm{s}$ firmou, jejíž akcie vlastní. Výhodou takového vztahu je jistě fakt, že majitel, který se přímo podílí na řízení své společnosti, má daleko přesnější a detailnější přehled o finanční situaci v podniku, než jaký má akcionár̆.

Naopak jistou nevýhodu představuje obtižnější zajištování financování. Malé firmy budou oproti velkým podnikům získávat úvěry daleko komplikovaněji, k financování tak používají především zadržování zisku a pozdější platbu dodavatelům. (1)

\subsubsection{Velké podniky}

U velkých společností zpravidla dochází $\mathrm{k}$ tomu, co bychom mohli nazvat delegací pravomocí. Skuteční vlastníci firmy svěřuji rízení svého majetku do rukou manažerů. Akcionáři nejprve zvolí představenstvo společnosti, které následně vybere a jmenuje tyto ředitele, jež jsou součástí tzv. top managementu firmy.

V důsledku toho tak dochází k něčemu, co Synek a Kislingerová (1) nazývají oddělením vlastnictví od ř́zení. Tento, v jistém slova smyslu, problém označujeme jako „corporate governance" neboli „struktura moci v podniku“. Manažeři v podstatě zastávají úlohu majitelů, ale ze své pozice musejí dbát nejenom na spokojenost těch, kteří je jmenovali, ale rovněž těch, prostřednictvím kterých dosahují stanovených cílů podniku - tedy zaměstnanců, dodavatelů nebo investorů.

Dalo by se namítat, že vzhledem $k$ tomu, že podnik není majetkem manažerů, nemají manažeři až takový zájem na uskutečňování a naplňování firemních cílů. Podle Begga (2) mají manažeři dva důvody, proč by se měli ztotožnit s majiteli a snažit se dosahovat co nejlepších výsledků:

- nízký zisk znamená i nízkou cenu akcií, tudíž je pro konkurenční podniky snazší a dostupnější akcie podniku na burze skoupit a následně se zbavit managementu, který do této situace podnik dostal. Manažeři jsou tak motivování $k$ dosahování výsledků tím, že v př́ipadě selhání jim hrozí nebezpečí ztráty zaměstnání. $V$ podstatě se tak jedná o negativní motivaci,

- naopak pozitivní motivací je, když akcionáři převedou část akcií př́mo na manažery, kteří tak mají prímý zájem na tom, aby cena akcií rostla.

Manažeři by nicméně neměli sledovat jen zájmy akcionářů. Jejich povinností by mělo být brát $\mathrm{v}$ úvahu i požadavky a potřeby dalších zájmových skupin, tzv. stakeholders (1). Zájmovými skupinami jsou např́klad zaměstnanci, zákazníci, dodavatelé, investoři atp. Všechny tyto skupiny jsou pro manažera $v$ realizaci stanovených cílů nepostradatelné, jelikož ovlivňují působení firmy. Tudíz musí brát ohled i na jejich blaho.

\section{3 Řízení v závislosti na vývoji stavební produkce}

Velké stavební společnosti, kterou je i Metrostav a.s., jsou založené na rozsáhlých strukturálních projektech, jakými jsou hlavně veřejné zakázky. Jejich příprava trvá poměrně dlouho. Pokud se tedy orgán veřejné moci rozhodne takovouto zakázku připravit, trvá i několik let, než se vyprojektuje, dojedná se čerpání peněz z evropských fondů, než se vysoutěží a než se začne skutečně stavět. 
Jak uvedl Ing. Jaroslav Petřík, vedoucí ekonomického úseku Divize 5 Metrostavu a.s., velké stavební firmy se do krize dostaly až ted'. Průměrný věk zakázky je $v$ Metrostavu a.s. přibližně 1,5 roku. $V$ prípadě Divize 5 , která se specializuje na tunely a velké strukturální projekty, bude trvání zakázky delší než dva roky.

$Z$ toho tedy plyne, že $v$ době, kdy ostatní odvětví ekonomiky jako průmysl, výrobu atp. postihla krize, měl Metrostav a.s. relativně velké množství práce, která byla zajištěna nasmlouvanými budoucími projekty a projekty, které v období po krizi dojižděly. Hovoříme o tzv. backlogu.

Problém tak nastal až s odstupem několika let. Podle Ing. Petř́ka byly doby, kdy tunelářská divize měla rozjeté tř̌i projekty. Ted' pracuje jen na jednom. Jako divize tak podnikají spíše v zahraničí nebo na Slovensku.

\subsubsection{Specifika finančního řízení ve stavebnictví}

Ve srovnání s průmyslovými podniky představuje stavebnictví velmi specifický a odlišný druh podnikání. V podstatě Ize konstatovat, že, co do podmínek, nikdy nenalezneme dva zcela totožné projekty.

Jako znaky typické pro stavebnictví můžeme například podle Petersona (3) vnímat:

- orientaci na projekt. Oproti tomu je výrobní podnik orientován na proces. Proces se dá částečně modifikovat, ale ve výsledku se jedná o pořád jeden a ten samý výrobek jen s pár úpravami. Podmínky pro výrobu daného výrobku budou více méně neměnné - továrna bude stát pořád na tom samém místě, zaměstnanci budou vyrábět místo jednoho výrobku druhý. Ve stavebnictví by něco podobného nefungovalo. Už jen podmínky jsou pro každý projekt specifické - místo stavby se pro každý projekt liší a s tím souvisí i dostupnost dělníků a stejně tak i materiálu.

- decentralizovanou výrobu. Stavební firma má sice většinou svou centrálu, jednotlivé projekty ale realizuje mimo ni. Ke každému projektu jsou pak přidělováni dělníci i vybavení, které se tak pohybuje ze stavby na stavbu. Není možné, aby dělníci celý život pracovali na stejném místě jako v továrně. Výjimku mohou tvořit stavební podniky, jež mají např́iklad vlastní betonárky, kamenolomy atp.

- platební podmínky. Nedílnou součástí stavebnictví jsou i pozastávky neboli zádržné. Je to částka, jejiž splatnost je většinou delší a investor si jejím splacením vymáhá dokončení stavby dodavatelem. Zádržné tak představuje problémy pro cash flow společnosti. Podnik sice vygeneroval výnosy určitého objemu, ty se ale liší oproti sumě, která skutečně přistála na účtu. Výrobní podniky zpravidla inkasují naráz vše, co odběrateli vyfakturovaly.

- hojné využití subdodavatelů. Stavebnictví se více než jakékoliv jiné odvětví vyznačuje častým využíváním subdodavatelů. S těmi podnik může uzavřít smlouvu, například když není schopen určité práce na stavbě provést vlastními silami, když je provést může, ale není to pro něj výhodné at už po časové nebo finanční stránce nebo když daná stavební činnost není předmětem jeho podnikání.

\subsection{Cíle finančního řízení podniku}

Finanční řízení podniku by nebylo nutné, pokud by jím podniky nesledovaly určité cíle. Cíle podniku se mohou dělit v závislosti na tom, zda jsou stanoveny strategickým, či operativním řízením. Nicméně veškeré dění ve firmě by mělo směřovat $k$ naplnění primárního cíle.

\subsubsection{Hodnota podniku versus zisk}

Primární cíl může každý podnik uchopit odlišně. Jak vysvětlují Synek s Kislingerovou (1), primárním cílem může být bud'to maximalizace zisku, nebo maximalizace hodnoty podniku. 
$\checkmark$ př́padě maximalizace zisku by manažeři neměli počítat $s$ celkovým ziskem, ale měli by se zaměřit na podíl zisku připadající na jednu akci a především pak na její růst v čase. Toto pojetí primárního cíle zohledňuje především zájmy akcionářů, kterým je, v př́padě, že to dividendová politika společnosti umožňuje, zisk vyplacen formou dividend. Takovéto chápání primárního cíle může přinést momentální uspokojení akcionářŭ, z dlouhodobého hlediska je ale tento postup neudržitelný.

Proti maximalizaci zisku tak stojí maximalizace hodnoty podniku. Ta může být chápána jako účetní hodnota, likvidační hodnota nebo tržní hodnota. Právě zvyšování tržní hodnoty podniku, respektive jeho akcií, může být považováno za další primární cíl. Zisk, který společnost vyprodukuje, se nevyplatí formou dividend, ale je použit, reinvestován do dalších aktivit podniku. Peníze tak z podniku nezmizí jako $v$ prípadě vyplacení dividend a tržní hodnota akcií, tedy ta hodnota, za jakou jsou akcie obchodovány na burze, stoupne.

\subsubsection{Dělení podnikových cílů}

Řízení podniku je možná definováno jedním primárním cílem, toho je ale dosahováno pomocí menších, dílčích cílů. Takové cíle můžeme rozdělit následovně (4):

- Finanční cíle

- Roční objem tržeb

- Zisková marže

- Rentabilita vlastního kapitálu (ROE)

- Podíl na stavebním trhu

- Vnitřní cíle

- Spokojenost zaměstnanců v zaměstnání

- Technologická účinnost, jakožto podíl hodnoty tržeb za práci provedenou vlastními pracovníky a celkovým počtem pracovních hodin

- Cíle v oblasti inovací a zdokonalování

- Kritérium vyjadřující operační efektivnost či účinnost. Dá se vyjádřit jako poměr tzv. claimů (požadavků) investora a počtu odpracovaných hodin v podniku za daný rok. $V$ tomto př́padě mohou být za claimy považován např́klad počet všech reklamací uplatňovaných investorem.

- Uspokojení klientů

- Jedná se sice o značně subjektivní a obtižně měřitelný cíl, ale pro činnost firmy je neméně důležitý než výše uvedené cíle.

- Vyjádřit se dá např́klad good-willem představující např́klad portfolio klientů podniku. Určit se dá i průzkumem spokojenosti klientů.

\subsection{Rizika v řízení stavebního podniku}

Podle slov docenta Tomka stojí za kolapsem stavební společnosti až v $80 \%$ př́padů špatný nebo nedostatečný management. A rizik působících na stavební firmu v oblasti managementu je opravdu nespočet. Každé hrozící riziko, které není dostatečně ošetřeno, může $v$ budoucnu vést až právě ke kolapsu společnosti.

Většina těchto selhání je způsobena snahou stavební firmy vypořádat se se dvěma či více riziky najednou. A jak stojí v knize "Managing the Profitable Construction Business" (5), i pro zkušený management je náročné čelit takovýmto překážkám a překonat je. $V$ knize je dále uvedena i velice zajímavá studie uskutečněná v zámoří, jejiž výsledek autoři shrnuli do následující věty:

„Události a rozhodnutí způsobující nezdar v podnikání se udály v období ziskových let."

Podle studie se události a rozhodnutí předcházející selhání společnosti udály $v$ jednom ze tři ziskových roků předcházející prvnímu roku ztráty. Tato informace nám v podstatě říká, že manažeři nesmí nikdy spát. A to ani v období růstu. 
Každá stavební společnost bude jednou čelit prvotním rizikům hrozícím ve stavebnictví a s jejím růstem porostou i nástrahy, kterým se musí vyvarovat. Rizika podle zmiňované studie spočívají a nastávají v následujících situacích a problémech.

\subsubsection{Nárůst ve velikosti projektu}

Zdaleka nejčastějším problémem způsobující selhání firmy je dramatický nárůst ve velikosti realizovaného projektu. Tato změna, jak již bylo řečeno výše, obvykle nastává během ziskových let. Nicméně důsledky této změny se mohou $v$ určitých př́padech ukázat ještě před samotným dokončením projektu.

Je sice samozřejmé, že s růstem společnosti přichází i růst zakázek. Mělo by ale platit, že velikost nových zakázek by neměla přesáhnout dvojnásobek velikosti největšího projektu, který firma dříve realizovala.

Autoři upozorňují na to, že není třeba se ani tak bát o to, zda bude projekt dokončen (pravděpodobně bude), ale zajímají se spíše o to, zda bude dokončen se ziskem.

\subsubsection{Neobeznámenost s novými geografickými oblastmi}

Změna prostředí, ve kterém stavební firma obvykle operuje, a problémy z ní plynoucí jsou přibližně tak obvyklé jako problémy předcházející selhání $v$ důsledku zvětšení velikosti projektu. I v tomto př́padě se autoři ptají spíše na to, zda na projektu v zahraničí udělal podnik zisk, než zda je schopný projekt dokončit.

$\checkmark$ případě realizace projektu $v$ zahraničí může i zaběhlý stavební podnik narazit. Problémem jsou obvykle odlišné zvyky, metody, procesy stavby, regulace, legislativa a pracovní podmínky.

I Metrostav a.s. momentálně působí v zahraničí. Tento krok byl částečně vynucen i tím, že v Česku není dostatek velkých veřejných zakázek (6). Za těmi tak Metrostav zamíril do zahraničí. Realizuje nebo realizoval silniční tunely na Islandu, v Norsku, dálniční průtah Varšavou nebo metro $v$ Helsinkách.

Celkově k roku 2015 působil Metrostav a.s. v sedmi evropských zemích. 


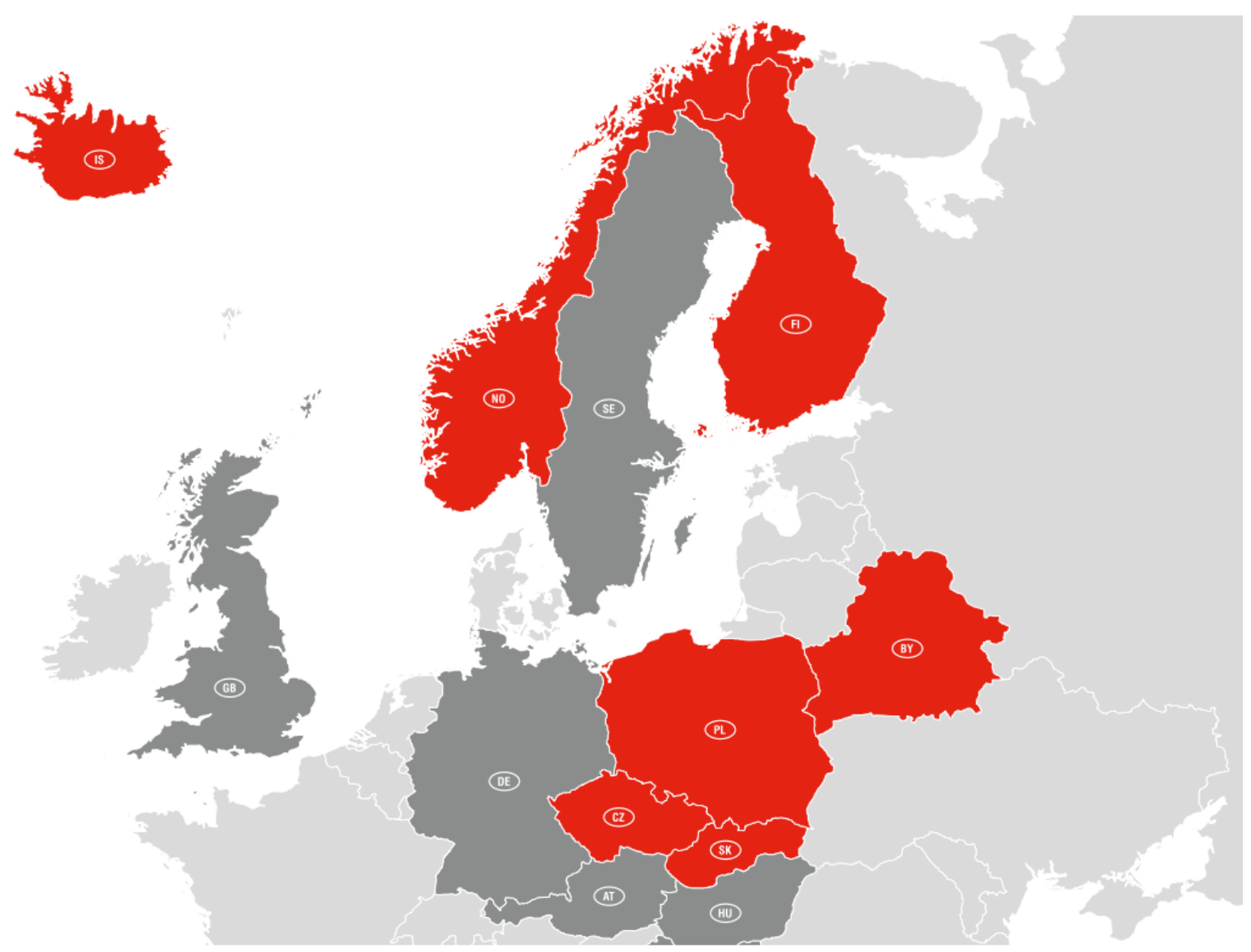

Obr. 1: Mapa působnosti Metrostav a.s. (červeně) a Skupiny Metrostav mimo Metrostav a.s. + USA a Kanada (tmavě šedivá) (7)

Právě v případě tunelů na Islandu nastal jeden z problémů související se zakázkami v zahraničí. V prípadě kontraktu z roku 2006 se přihodilo to, že kurz islandské koruny se proti euru propadl více než o polovinu, což mělo za následek i sní̌ení hodnoty zakázky. I přesto, že se tehdy Metrostav dohodl s investorem na dodatečném navýšení kontraktu, na celé zakázce prodělal. A to i z toho důvodu, že situaci ještě před samotnou realizací projektu podcenil a nepojistil se proti kurzovým ztrátám. (8) Metrostav a.s. na této zakázce sice prodělal, nicméně si alespoň vylepšil svůj good-will, který uplatnila v následujících letech, kdy na Islandu vyhrála další zakázky na ražbu tunelů.

Jako další příklad zakázky, na které se Metrostav a.s. v zahraničí podílel, uvádí Ing. Petřík tunely v Norsku. Na této stavbě jde ale naopak demonstrovat jistou výhodu oproti české praxi. $V$ Norsku je zástupce investora na stavbě 24 hodin denně, takže pokud hrozí, že by došlo k vícepracem, dodavatel se zástupcem investora rovnou na stavbě nastalou situaci zváží a následně víceprace odsouhlasí, či zvolí jiný postup. Tím je nárok dodavatele rovnou vyřešen a investor již nemá právo zpochybňovat, zda je navýšení ceny zakázky oprávněné, či nikoliv.

\subsubsection{Přesun do nových oblastí stavebnictví}

Stavební společnosti se čas od času uchylují k rozšíření portfolia jimi vykonávaných prací. V takovém případě jsou si firmy dobře vědomy potřeby udělat před takovým krokem detailní průzkum a stanovit plán této operace. Co už ale bývá drasticky podceněno, je „vstupní cena“ na tento trh. Vstupní cenou je myšlena částka, kterou společnost zaplatí za období aklimatizace v nové sféře podnikání.

Společnosti tento krok obvykle řeší zaměstnáním zkušené osoby z oboru, toto řešení ale většinou není dostatečné. Součástí transferu do nové sféry, se kterou musí podnik počítat, jsou i počáteční neúspěchy. Ty mají v mnohých př́ípadech existenční dopad. 
Přesun se nicméně nemusí týkat jen změny z inženýrských staveb k výstavbě kancelářských budov. Relativně méně citlivou změnou může být přesun ze zakázek zadávaných veřejným sektorem na veřejný a naopak.

I v tomto případě si musí stavební společnost uvědomit specifika obou sektorů:

- Úspěšné přihlášení do soutěže

- Kritéria pro výběr dodavatele

- Poměr spolupráce mezi dodavatelem, investorem a dalšími

- Kvalita práce očekávaná a realizovaná

- Velikost předpokládaných změn umožněných po nabídce nebo vynucených v průběhu stavby

\subsubsection{Výměna klíčových zaměstnanců}

Autoři vymezují tři primární oblasti stavebního byznysu, které musí být zvlášt řízeny a kontrolovány tak, aby vytvořily úspěšné podnikání. Dělení je následující:

- Odhad a prodej = získávání práce

- Stavební výroba = realizace práce

- Administrativa a účetnictví = řízení podnikání

V každé úspěšné stavební firmě je za každou jednu oblast zodpovědný vrcholový manažer, nebo se o zodpovědnost nad všemi oblastmi dělí jeden či dva lidé.

Pokud podnik generuje zisk, děje se tak primárně díky úsilí těchto lidí. Pokud někdo z těchto manažerů podnik opustí, zmizí s ním i část podnikové historie a zkušenosti, která bude muset být nahrazena novou organizací. $V$ úspěšných firmách se navíc nestává, že by byla zodpovědnost za tyto tři primární oblasti byla delegována na střední management.

Stavební společnosti jsou tak neustále vystavené riziku, že někdo z vrcholových manažerů společnost opustí. Navíc ve srovnání s ostatními průmyslovými odvětvími je ve stavebnictví vrcholový management poměrně malý. Je to způsobené především tím, že stavební společnosti mají na různé typy práce subdodavatele, nemusí tak obsáhnout všechna odvětví stavebnictví. Najít tak adekvátní náhradu může být velmi náročná záležitost. Pokud se podnik uchýlí $k$ angažování někoho méně schopného, vystavuje se značnému riziku. Tento problém se obvykle objevuje během období, kdy je společnost $\mathrm{v}$ zisku.

\subsubsection{Vyspělost manažera}

Velmi častým problémem, který se nevyskytuje zdaleka jen ve stavebnictví, je selhání společnosti v důsledku nedostatečně zkušeného managementu. Toto riziko se obvykle projevuje společně $s$ výše uvedenými problémy a často přispívá ke zhoršování jejich stavu. Potřeby managementu se liší v závislosti na velikosti společnosti. Vlastnosti manažera malé společnosti nemusí být na takové úrovni jako manažera velké firmy.

$\checkmark$ malých společnostech je většinou jejich vlastník i jejich manažerem, jehož domněnka většinou bývá: „Když dokážu postavit takové množství, zvládnu i dvakrát tolik.“ Termín „vyspělost manažera“ je tu tudíž užit proto, že i manažer musí být dostatečně vyspělý na to, aby si uvědomil, že s rostoucím objemem prací rostou i manažerské potřeby na její vykonání. Manažer si musí uvědomit, že s růstem společnosti roste i zodpovědnost, kterou je potřeba delegovat a rozprostř́t na více osob a zvýšit tak její efektivnost. Firmy, které nepřistoupí ke změně organizace pravomocí a zodpovědnosti pravděpodobně nikdy nedosáhnou na takový zisk, jaký by mohly vytvořit v případě přeměny. 


\section{Controlling a reporting}

Jedním z hlavních poslání manažera ve stavebném podniku je získávat nové zakázky. Vítězstvím ale jeho práce zdaleka nekončí. Důležité je se o zakázku starat. Právě $\mathrm{k}$ tomu je ve stavebním podniku používán controlling, který sleduje náklady vynaložené na materiál, pracovní sílu, subdodávky, vybavení a např́iklad správní režii. (4)

Díky nástrojům controllingu je manažer schopný říct, jak se tomu kterému projektu daří, a dokáže identifikovat problémové oblasti, kterých by se měl projekt následně snažit zbavit. Zároveň musí být schopný předat informaci formou reportů bud'to výše ve firemní hierarchii - informovat vedení podniku, jak si daná zakázka stojí - nebo naopak níže - předat podřízeným informaci o tom, jaký bude u daného projektu další postup.

\subsection{Controlling ve stavebním podniku}

Controlling ve stavebním podniku tvoří jednu ze základních složek práce managementu. Jeho začlenění ve firemní hierarchii se může lišit podnik od podniku v závislosti na organizační struktuře.

$\checkmark$ podnicích bývá pozice controllingového oddělení bud'to na úrovni štábní, liniové, může mít prưřezovou funkci nebo $v$ prípadě menších a středních podniků bývá uskutečňována externě. (9) Takovéto rozdělení ale není př́liš vhodné pro stavební podniky. $V$ př́padě jednotlivých stavebních projektů a zakázek bývá controlling zpravidla začleněn co nejblíže řízení. Největší díl zodpovědnosti nese většinou projektový manažer a s ním stavbyvedoucí, kteří zároveň zastávají funkci „controllerư“. Controlling ve velké stavební společnosti je zpravidla uskutečňován na úrovni projektu, divize, centrály a následně prezidia, které pro zpětnou kontrolu činností ve společnosti používá i nástrojů interního auditu, jenž má například $v$ Metrostavu a.s. za primární cíl ověřit, zda byly při řízení dodrženy všechny postupy a pravidla uvedená v organizačně-řídících normách (OŘN).

Nicméně nehledě na to, jak bude controlling do podniku začleněn, ve stavební praxi bude mít na starost především správu a kontrolu následujících oblastí. (4)

\subsubsection{Nákup materiálu}

Kontrola nákupu a spotřeby materiálu patří $\mathrm{k}$ jedněm $\mathrm{z}$ nejdůležitější kontrolovaným věcem $u$ jednotlivých projektů. Samotný nákup musí být jasně specifikován. Projektoví manažeři by měli v objednávce jasně specifikovat, jaké množství a $v$ jaké ceně objednávají, a následně objednávku schválit. Jasné musí být i druh materiálu a především doba, kdy bude potřeba na stavbě.

U velkých projektů by měla probíhat velmi úzká spolupráce se stavbyvedoucím, jenž má rovněž právo provádět objednávky, nicméně $v$ jeho prípadě by neměly dosahovat takové hodnoty jako $u$ projektového manažera. Menší nákupy jsou uskutečňovány většinou v případě, kdy by nedostatek materiálu mohl způsobit prostoje na stavbě a prodloužení celého projektu. Pokud se ale menší objednávky opakují častěji, indikuje to nedostatečnou a ne přiliš kvalitní přípravu projektu. (4) Schvalování objednávek dává managementu možnost kontroly, zda jsou náklady $v$ souladu $\mathrm{s}$ rozpočtem a že je objednáván jen skutečně potřebný materiál pro daný projekt a nekončí nikde mimo stavbu. 


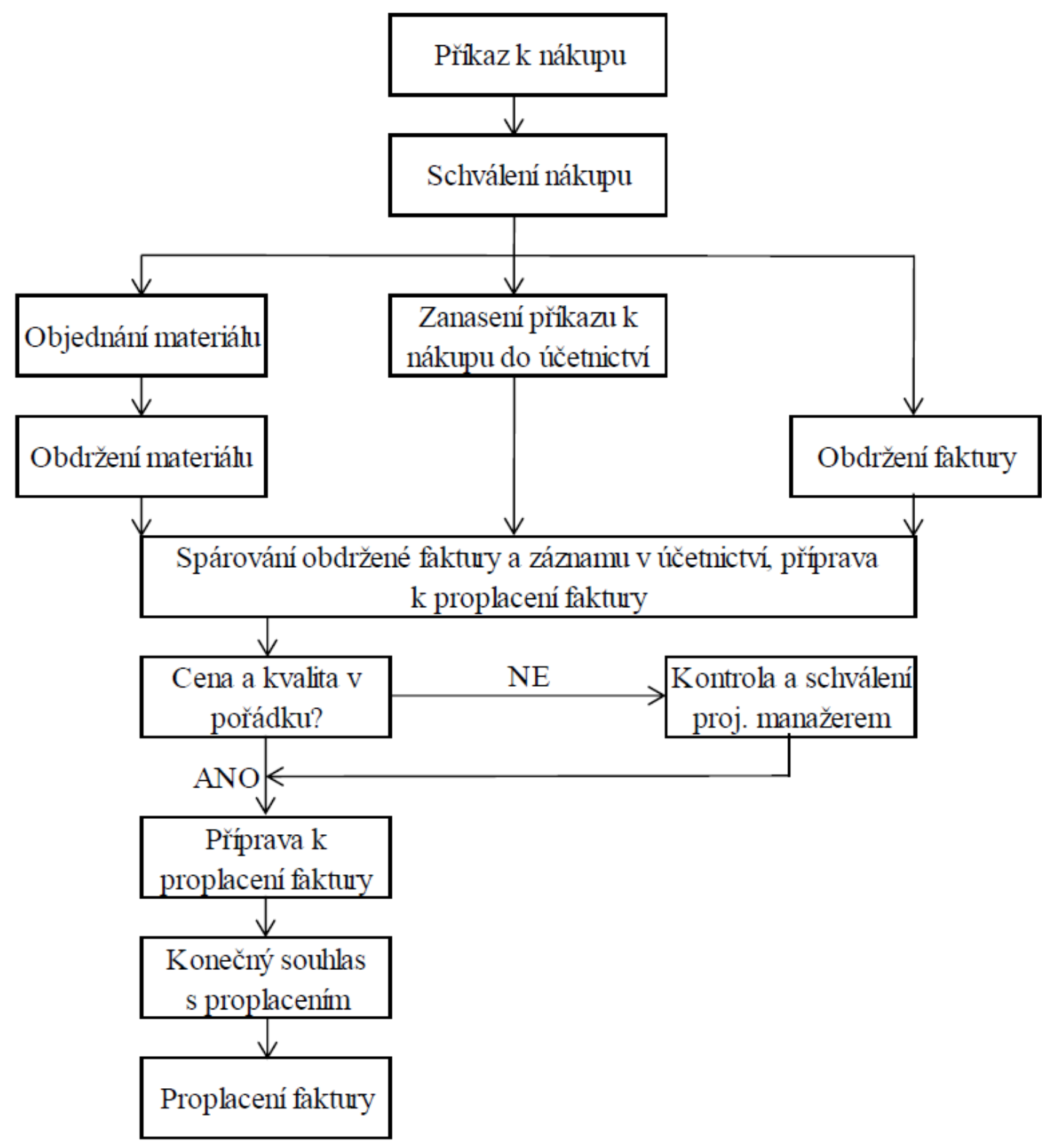

Obr. 2: Postup při nákupu materiálu (4)

\subsubsection{Práce}

V př́ípadě práce je její kontrola daleko složitější a náročnější než u materiálu. U nákupu materiálu je pro projektového manažera lehce kontrolovatelné, kdy a v jaké ceně k obdržení materiálu došlo.

Náklady spojené s prací na daném projektu je možné vyčíslit až po jejich odvedení a zanesení pracovní doby zaměstnanců do účetních systémů, což se může stát i týden či déle poté, co byla práce odvedena. (4)

$\checkmark$ prípadě kontroly práce je pro projektového manažera důležitá spolupráce se stavbyvedoucím, respektive stavebními mistry, kteří jsou zodpovědní za produktivitu a náklady na práci. 


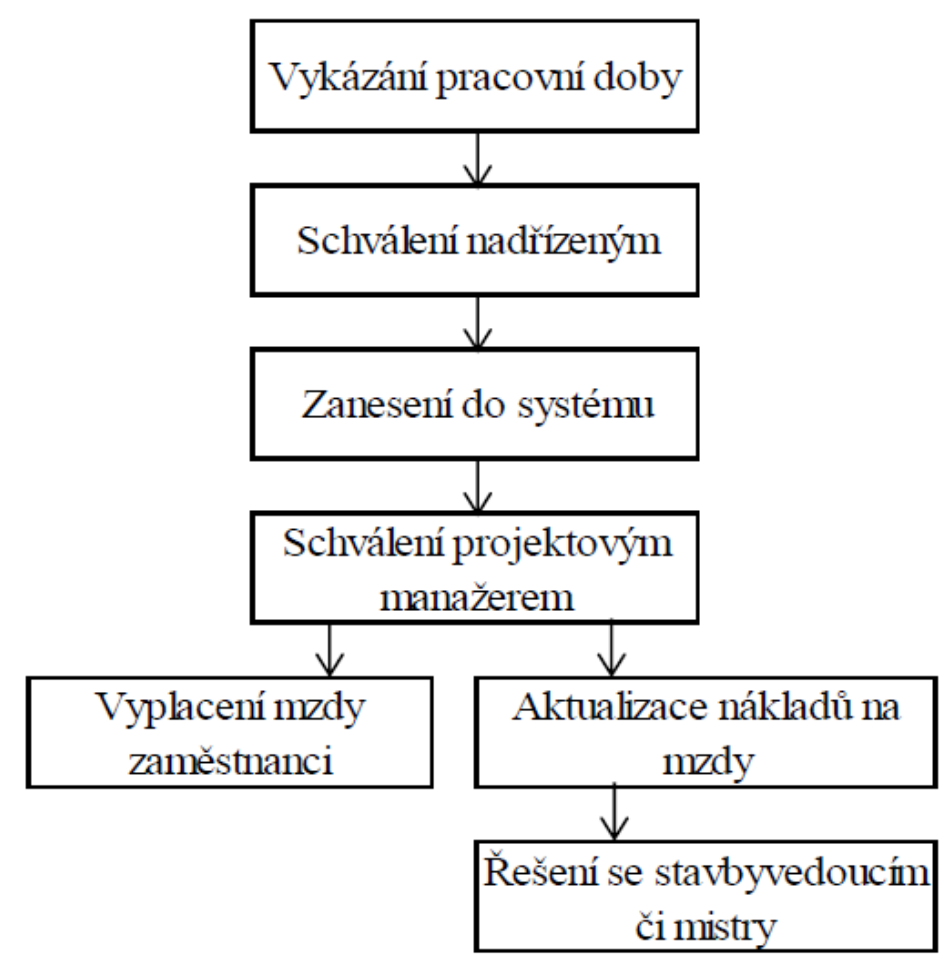

Obr. 3: Postup při nákupu práce (4)

\subsubsection{Subdodávky}

$\mathrm{Na}$ rozdíl od nákupu materiálu, všechny faktury od subdodavatelů by měly projít rukami projektového manažera ještě předtím, než vstoupí do systému a budou proplaceny. Dưvodem tohoto postupu je fakturace od subdodavatele, který většinou fakturuje průběžně na základě prostavěnosti.

Ve srovnání s používáním materiálu je daleko těžší určit, kolik práce subdodavatel na stavbě skutečně odvedl a zda jím fakturovaná částka odpovídá tomu, v jakém stádiu rozpracovanosti se nachází jeho subdodávka. Projektový manažer tak určuje, zda jsou faktury od dodavatele férové a zda je možné je proplatit. (4) 


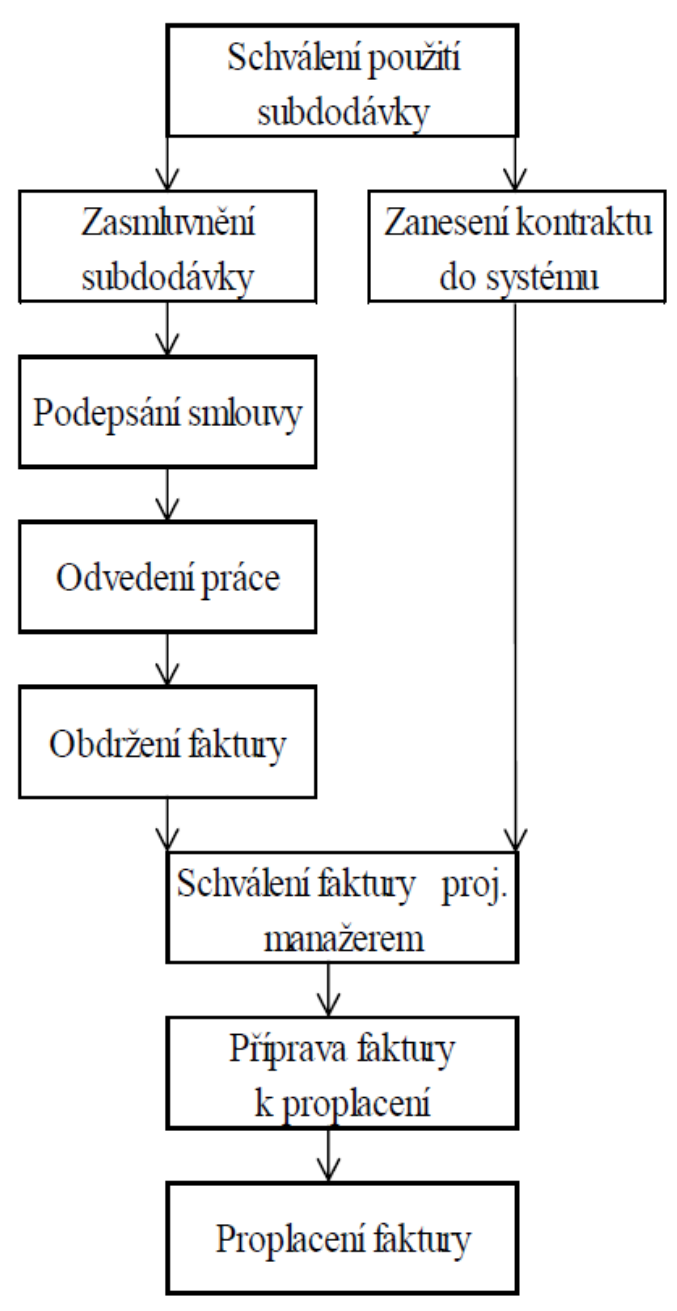

Obr. 4: Postup při nákupu subdodávek (4)

\subsubsection{Stroje a další zařízení a vybavení}

Stejně jako $v$ př́padě práce jsou $\mathrm{i}$ náklady spojené se stroji a dalším vybavením těžko kontrolovatelné. Podobně jako $v$ prípadě zaměstnanců i u strojů by měly být vedeny určité výkazy práce. Pokud je jasné, že určitý zaměstnanec vždy používá ke své práci určitý stroj, může se výkaz práce stroje nahradit výkazem práce zaměstnance.

Náklady spojené s používáním strojů a dalšího vybavení by se měly být fakturovány $\mathrm{v}$ závislosti na činnosti, na které se podílely. Vykazovány by měly být hodiny práce poprípadě dny, kdy byl stroj na stavbě.

S tím je spojena i povinnost projektového manažera případně stavbyvedoucího ohlídat si, že se na stavbě nevyskytují nepotřebné stroje, které by akorát zbytečně navyšovaly náklady stavby.

Je nutné brát ohled i na to, že počáteční částka v rozpočtu daného projektu vyčleněná na stroje je pouhým odhadem a její skutečná hodnota se mění den ode dne a reálnou hodnotu je možné vyčíslit až na konci projektu. Projektované částky vychází ze zkušeností podniku na předchozích zakázkách.

Náklady jakožto pronájem, leasing, odpisy, daně, licence a pojištění jsou lehce stanovitelné již na začátku projektu, problém nastává u nákladů spojených s provozováním stroje. Na začátku projektu je těžko odhadnutelné, kolik daný rok vynaložíme na opravy, údržbu, palivo, atp. Tyto náklady jsou závislé na používání stroje a jejich hodnota se liší v závislosti na podmínkách, v jakých stroj pracuje. Vzhledem $\mathrm{k}$ tomu je nutné srovnávat plánované náklady s realitou nejméně jednou do měsíce. $\mathrm{Na}$ konci roku či účetního období se pak reálné náklady musí shodovat s číslem vykazovaným v účetnictví. 
Pokud management nadhodnotí náklady strojů na daném projektu, má to za následek to, že se zvýší i výsledná cena projektu a rozpočet stavby se tak bude jevit jako nedostatečný. $V$ prípadě podhodnocení nákladů na stroje se bude rozpočet jevit sice dostačující, realita může být ale naprosto opačná. Problém nastane i v prípadě, že bychom na základě takto podhodnocené zakázky připravovali další projekty a vycházeli bychom z podhodnocených čísel pro kalkulaci nákladů nového projektu. (4)

\subsubsection{Ostatní náklady}

Pokud je to jen trochu možné, ostatní náklady na stavbě by měly být fakturovány podobným způsobem jako nákup materiálu. $V$ případě, že takovýto postup není možný, je nutné poslat fakturu $\mathrm{k}$ odsouhlasení projektovému manažerovi, následně musí být zanesena do systému a teprve potom může být faktura zaplacena. (4)

\subsubsection{Režijní náklady}

$\checkmark$ př́padě režijních nákladů by se mělo postupovat stejně jako u nákupu materiálu nebo subdodávek. Projektový manažer by měl hlídat projektové náklady a režie by měly být srovnávány $\mathrm{s}$ hodnotou uvedenou v plánu alespoň týdně a následně měsíčně. Stejně jako u všech předchozích nákladů platí, že náklady, které nejsou aktivně sledovány a porovnávány, se rychle dostanou mimo kontrolu. (4)

\subsubsection{Sledování ziskovosti projektu}

Náklady spojené s daným projektem by měly být pečlivě sledovány a monitorovány a to nejlépe na týdenní bázi. Sledovat by se mělo především porovnání skutečných nákladů stavby s plánovanými, což by mělo být následně podkladem pro aktualizaci nákladů na dokončení projektu. Všechny náklady by měly být zaneseny do účetního systému, na jehož základě může následně probíhat přesnější a rychlejší kontrola. (4)

Díky kontrole a sledování vývoje zakázek bývají často odhaleny problémy typu špatného nacenění a naplánování zakázky, nízká produktivita práce nebo jsou odhaleny chyby v zadávání hodnot do účetního systému. Zcela speciálním problémem ovlivňující stavební produkci je pak vliv špatného počasí.

Možností, jak se pojistit před vlivem těchto rizik, je vytvoření tzv. rizikové přirážky, jež je zahrnuta v celkové ceně projektu a z níž je možné čerpat peníze na výše uvedené problémy. (4) Nicméně v dnešní době je ve stavebnictví téměř nemožné $s$ rizikovou přirážkou kalkulovat. U zakázek, kde figuruje hodně zájemců, musí firma jít s nabídkovou cenou „na krev“, aby zakázku vyhrála. Podle Ing. Petříka z Metrostavu není při nabídkové ceně na rizikovou přirážku žádný prostor.

Každá stavební firma má $\mathrm{k}$ dispozici pro vyhodnocování zakázky svůj vlastní formulář, na základě jehož reportuje vedení společnosti o vývoji té a té zakázky. Ani Metrostav a.s. není výjimkou.

\subsubsection{Plán nákladů}

Plán nákladů funguje na základě časového plánu, nicméně kromě data zahájení a dokončení daného úkolu z něj vyčteme i to, kolik v daný den, týden či měsíc za práce zaplatíme. Usnadňuje tak plánování cash flow.

Jak již bylo řečeno, jeho př́íprava probíhá na základě časového plánu, kde jsou $\mathrm{k}$ jednotlivým činnostem rozpočítány náklady například do jednotlivých dnů. Jejich následnou sumarizací Ize dosáhnout zjištění nákladů $v$ jednotlivých týdnech či měsících. Záleží, jak často je potřeba kontrola nákladů u daného projektu. (4)

\subsubsection{Index SPI}

Index SPI (Schedule Performance Index) vyjadřuje úspěšnost projektového managementu v plnění zakázky ve stanovený čas. Princip tohoto indexu je založen na vztahu plánovaných nákladů na 
skutečně odvedenou práci na daném úkolu a plánovaných nákladech na plánovanou práci. Index SPI je poté vyjádřen jako podíl těchto dvou hodnot.

Pokud je poměr těchto dvou čísel větší než 1 , neboli že skutečně odvedená práce je větší než plánovaná, poté je projekt napřed oproti plánu. (4)

Pokud se SPI rovná jedné, projekt se nachází přesně tam, kde má podle časového plánu být.

Ve třetím prípadě, kdy je SPI menší než 1 , je skutečná práce odvedená na projektu menší než plánovaná a projekt se tak nachází ve skluzu.

Výhodou indexu SPI je, že neuvažuje jen činnosti na kritické cestě, ale bere v potaz náklady na všechny činnosti probíhající na stavbě $v$ dané období. $V$ př́padě, že se bere v potaz jen kritická cesta, může se stát, že činnosti, které se na kritické cestě nenachází, se dostanou do skluzu.

Naopak jistou nevýhodou tohoto indexu je jistá generalizace. Činnosti na kritické cestě jsou začleněny do výpočtu s ostatními činnostmi, což může způsobit to, že celkově sice bude projekt stavěn v souladu s plánem, samotné činnosti na kritické cestě se ale mohou nacházet ve skluzu. I kvưli tomuto důvodu se doporučuje používat index SPI společně s plánem kritické cesty. (4)

\subsubsection{Index CPI}

Index CPI (Cost Performance Index) vyjadřuje, jak moc se projektovému managementu daří plnit zakázku v souladu s rozpočtem. Tento index vyjadřuje poměr mezi plánovanými náklady a skutečnými náklady, které Ize vyčíst z účetního systému.

Pokud index CPI vychází méně než 1 , značí to, že plánované náklady byly větší než skutečné a projekt se tak nachází v mezích rozpočtu.

$\checkmark$ případě, kdy se CPI rovná jedné, je projekt stavěn plně v souladu s rozpočtem. Pokud je index menší než jedna, rozpočet je nedostačující a skutečné náklady větší než plánované.

Nevýhodou indexu CPI je ten fakt, že nemůže být vypočten dřive, než jsou náklady za dané období zaneseny do účetního systému. Objektivnost tohoto indexu je tudíž ovlivněna tím, jak společnost fakturuje a jak je jí fakturováno od subdodavatelů atp. (4)

\subsubsection{Konečné vyhodnocení zakázky}

Na konci každé zakázky, kdy jsou známé všechny náklady a výnosy, je nutné provést vyhodnocení zakázky. Správně by mělo vyhodnocení proběhnout až po

konci záruční doby, během které ještě mohou vzniknout náklady spojené s odstraněním závad.

Vyhodnocení zakázky poskytuje podklad pro přípravu dalších nabídek a zároveň i doporučení, jak v budoucnu postupovat a čemu se raději vyhnout. Zároveň by z něj mělo být zřejmé, jaké problémy nastaly a jak byly řešeny.

Vyhodnocení zakázky by mělo sestávat ze tří částí. (4) První část by se měla věnovat správnosti účetních dat projektu. $V$ prípadě, že se projektový manažer věnoval nákladům vzniklým na stavbě každý týden, neměl by být ve správnosti hodnot zakázky problém. Ten nastává v př́padě, že se náklady kontrolovaly $v$ delším časovém horizontu.

Důležitost správnosti dat je podstatná pro přípravu dalších nabídek, jejichž příprava probíhá právě na základě již vyhodnocených projektů.

Druhou oblastí je zaměření se na oblasti zakázky, kde se projektu dařilo lépe, než bylo plánováno. Management by měl identifikovat faktory, které tento fakt způsobily, a následně je uplatnit na dalších zakázkách. Peterson (4) uvádí jako př́klad častější schůzky se subdodavateli. Pokud se dodavateli jeví jako prínosné, že o dané zakázce jednal se subdodavateli každý týden, měl by tento postup aplikovat i u dalších staveb. 
Obdobně by se měl management zaměřit i na oblasti, kde se projektu naopak nedařilo. $V$ takovém případě je nutné identifikovat původ problémů a v př́štích se jich vyvarovat.

\subsection{Reporting ve stavebním podniku}

Kromě výše uvedených formulářů pro vyhodnocování zakázek a nákladů, které budou ještě blíže specifikovány $v$ praktické části této bakalářské práce, jsou v př́padě Metrostavu a.s. dostupné dva oficiální dokumenty určené především pro externího uživatele.

\subsubsection{Výroční zpráva}

Prvním z těchto dokumentů je výroční zpráva. Tu je nutné zveřejňovat každý rok a rídí se zákonem č. 563/1991 Sb., o účetnictví, ve znění pozdějších předpisů. Její hlavní náplní je účetní závěrka, výkaz zisku a ztrát a další prílohy, jimiž jsou především přehled o peněžních tocích (cash flow) a přehled o změnách vlastního kapitálu.

Podle zákona č. 563/1991 Sb., o účetnictví, ve znění pozdějších předpisů (10) musí kromě informací nezbytných pro naplnění účelu výroční zprávy dále obsahovat nejméně finanční a nefinanční informace:

- o skutečnostech, které nastaly až po rozvahovém dni a jsou významné pro naplnění účelu výroční zprávy,

- o předpokládaném vývoji činnosti účetní jednotky,

- o aktivitách v oblasti výzkumu a vývoje,

- o nabytí vlastních akcií nebo vlastních podílů,

- o aktivitách v oblasti ochrany životního prostředí a pracovněprávních vztazích,

- o tom, zda účetní jednotka má pobočku nebo jinou část obchodního závodu v zahraničí,

- požadované podle zvláštních právních předpisů.

\subsubsection{Roční zpráva}

Druhým dokumentem, který Metrostav a.s. každoročně vydává, je tzv. roční zpráva. Její znění není regulováno zákonem, v podstatě se jedná o dobrovolně tvořený dokument.

$\checkmark$ prípadě Metrostavu a.s. nejsou $v$ ročních zprávách uváděny podrobné finanční výsledky společnosti. Naopak zde nalezneme slovní hodnocení uplynulého roku, podrobnější popis strategických cílů, než je tomu ve výroční zprávě a další informace o rozvoji společnosti a neúčetních výsledcích její práce (například počet proražených metrů tunelů, počet položených kilometrů železničního svršku nebo počet vyrobených tun asfaltu. A to jak v př́ípadě Metrostavu a.s., tak Skupiny Metrostav.

Další informací, již $v$ roční zprávě nalezneme, je informace o tzv. Prioritě společenské zodpovědnosti. $V$ této části zprávy jsou uvedeny definovány priority firmy, které Metrostav a.s. umist'uje do oblastí, ve kterých má významné environmentální, společenské a ekonomické dopady.

(11) Těchto priorit je celkem šest:

- transparentní podnikání,

- inovace ve stavebnictví,

- podpora zaměstnanců,

- bezpečnost na stavbách,

- ochrana životního prostředí,

- firemní občanství. 


\subsection{Controllingové nástroje a reporting v Metrostavu a.s.}

$S$ velikostí stavební firmy je spojená i míra controllingu a reportingu uvnitř společnosti. Vzhledem $\mathrm{k}$ tomu, že Metrostav a.s. je největší stavební firmou na českém trhu (6), musí míra kontroly uvnitř firmy pokrýt hned několik úrovní. Controlling probíhá od projektů, přes divize, až na centrálu, která je posléze ještě navíc kontrolována interním auditem stojícím na úrovni prezidia Skupiny Metrostav.

Základní řízení nákladů jednotlivých projektů probíhá na divizích a je založeno na existenci následujících dokumentů.

\subsubsection{Divizní smlouva}

Ročně se uzavírá divizní smlouva, která je mezi divizí a vedením. V ní se podepisují plánované hodnoty, kterých divize dosáhne, včetně úrovně zisku. Tyto hodnoty jsou založené na tom, že projekty dávají v nějakém širším měřítku roční výhled jak jejich obratu, tak i jejich rentability, z čehož je divize a vedení schopné určit reálnou hodnotu, na kterou se následně uzavře smlouva.

Tento dokument je pro divizi směrodatný po celý rok a hodnoty uvedené ve smlouvě slouží k porovnání, jak moc se divize bliží, nebo nebliží plánu.

Naprosto stěžejní a nejdůležitější hodnotou uvedenou $v$ divizní smlouvě je úroveň externího obratu. Externího proto, že ještě v rámci Metrostavu a.s. si mezi sebou jednotlivé divize fakturují. Kromě externího obratu je důležitá i rentabilita. A to jak celé divize, tak potažmo jednotlivých projektů.

Hodnota externího obratu se skládá z hodnot obratu z již rozpracovaných zakázek, ze zakázek, které jsou již zasmluvněné, ale ještě se nezačaly stavět, a ze zakázek, které by se podle předpokladu měly na toto období ještě zasmluvnit.

Kromě externího obratu a rentability jsou v divizní smlouvě uvedeny i informace o personálu, které jsou rovněž v průběhu roku porovnávány se skutečností.

Na úrovni divize není prováděna ani finanční analýza. Tu provádí až interní audit na úrovni prezidia.

\subsubsection{Hodnocení divize}

Hodnocení divize se provádí každé čtvrtletí. Takové hodnocení spočivá v tom, že vedení divize se sejde s vedením Metrostavu a vznikne dokument, který se skládá z několika částí.

Jednou částí je část obchodní - ta udává, kolik ze zakázek, které jsou realizované, obchodně zbývá, jaké zakázky jsou před zasmluvněním a o jaké divize soutěží.

Další částí je část ekonomická, kde jsou uvedeny výsledky jednotlivých projektů získané z vnitropodnikového systému. Je zde okomentováno, proč mají některé projekty problémy a co je způsobilo. Je to stěžejní report, který se probírá oficiálně s vedením Metrostavu a divize.

Na poslední čtvrté čtvrtletní schůzce, která je v daném roce zároveň poslední, se vyhodnotí, jak divize dopadla $v$ daném roce ve srovnání s divizní smlouvou. Jestli splnila plánované hodnoty, jestli je splnila s výhradou atd. Toto hodnocení má napůl textovou formu, napůl jsou to výstupy z podnikového systému.

Na úrovni centrály vznikají reporty na Skupinu Metrostav, kde se schází tzv. Rada ředitelů, kde se probírají maximálně divize. Hlouběji se nejde. Maximálně se zmíní, že tato divize má nějakou problémovou zakázku a jak si tato zakázka stojí. Ale projekt po projektu se na Radě ředitelů nerozebírá.

Dále se ještě obchodní, ekonomický i výrobní náměstek chodí zpovídat obchodnímu, ekonomickému a výrobnímu řediteli. Z těchto měsičních sezení nevzniká žádný oficiální dokument, který by se archivoval jako $v$ prípadě čtvrtletních hodnocení divize. 


\subsubsection{Vyhodnocení stavební zakázky}

Vyhodnocení stavební zakázky probíhá v několika úrovních. Základní hodnocení zakázek, které jsou svým způsobem rizikové, probíhá čtvrtletně formou vytýkacích řízení. Vedení divize se sejde $\mathrm{s}$ vedením projektu a proberou problémy, které nastaly a jakým směrem se projekt rítí. Hodně se probírá claimová agenda. $V$ dnešní stavební praxi je totiž vedoucí projektu tím jediným, se kterým se investor baví a řeší s ním své požadavky.

Další vyhodnocení probíhá vždy po zakázce a dále po uplynutí záruční doby.

Ve vyhodnocení zakázky po jejím předání se revidují a zkoumají hodnoty dosažené u jednotlivých zakázek v bilancích a porovnávají se s hodnotami uvedenými v řídící smlouvě a smlouvě s investorem. Dále se vyhodnocuje jakost, rizika přítomná prímo na stavbě, ochrana životního prostředí a použité technologie.

Tím, že má Divize 5 velké projekty, tak její rízení zakázek probíhá jinak než na ostatních divizích. Na projektu pracuje vždycky minimálně vedoucí projektu a ekonom, který se právě ne vždy u projektů takto prímo figuruje. Ekonom projektu je někdo mezi ekonomem a výrobním manažerem, který musí vědět, co se na stavbě děje ve vazbě na to, jaká je fakturace.

\subsection{4 Řídící smlouva}

Obdobou divizní smlouvy je smlouva řídící. Tu uzavírá vedení Metrostavu a.s. s vedoucím projektu. Vedoucí se ve smlouvě zavazuje realizovat $v$ určitých termínech, finančních limitech a s daným hospodářským výsledkem. Je to oficiální právnický dokument, který, když vedoucí projektu dosáhne stanovených parametrů a Metrostav a.s. by mu odmítl nezaplatit, tak se může s vedením společnosti soudit.

Př́lohou této smlouvy je i seznam členů projektového týmu, prémie, která jim při splnění podmínek ve smlouvě připadne, a obdoba přehledu základních ukazatelů smlouvy s plánovanými hodnotami nákladů na jednotlivé stavební a správní oddíly.

\subsubsection{Přehled základních ukazatelů stavby}

Projekty reportují každý měsíc, dělají tzv. bilance. Bilance spočívají v tom, že zbilancují měsíc, který je již uzavřený, odhad na měsíc, který je aktuální, a také ještě další výhled na měsíc dopředu.

Každý měsíc se provádí i účetní závěrky, kde podle toho, jak projekty fungují, tak padají výnosy a náklady do účetnictví. Případně se ještě hodnoty v účetnictví upravují nástroji, jako jsou rezervy prípadně nedokončená výroba.

Bilance se provádí formou formuláře, který se liší v závislosti, zda se jedná o domácí nebo zahraniční projekty. $V$ podstatě je to podrobnější struktura toho, z čeho se skládají výnosy a náklady v daném období, ve kterém se zrovna bilancuje.

Kromě běžných reportů a kontrol probíhají výjimečně i další operativní controllingové akce a to především u rizikovějších, krizovějších projektů. U nich se přistupuje k porovnání nákladové kalkulace se skutečností, respektive odhad do konce projektu.

Každý projekt má určitou nákladovou strukturu, která se sleduje za projekt jako takový bez ohledu na to, $v$ jakém měsíci náklady nastaly. Berou se hodnoty od začátku do konce projektu. $V$ nákladové struktuře existuje plán, ke kterému padá určitým způsobem skutečnost a také tzv. projekce. Jedná se v podstatě o odhad, jak daná zakázka dopadne.

Bilance je stěžejní report ze zakázky. Pokud se ekonomické oddělení divize baví s vedoucím projektu nebo naopak s vedením o tom, jak zakázka vypadá nebo kam spěje, tak právě bilance slouží jako určitý výkaz ze systému a podklad.

Plánované hodnoty v bilanci se zároveň přebírají do př́lohy řídící smlouvy. 


\section{Závěr}

Cílem této práce bylo seznámit její čtenáře s důležitostí a podstatou finančního řízení ve velké nadnárodní stavební firmě. Na několika dokumentech bylo vysvětleno, $v$ čem spočívá controlling $v$ Metrostavu a.s., jaké parametry jsou pro podnik i jednotlivé divize stěžejní a jak probíhá kontrola těchto parametrů. Čtenáŕ by měl z textu pochopit, že bez účinného řízení nejde dosáhnout dlouhodobě uspokojivých hospodářských výsledků.

Cílem zároveň bylo představit ekonomii respektive finanční řizení jako vědu, jež by měla být v současném světě chápána jako to nejdůležitější odvětví. Protože bez správného finančního řízení, nejenom ve stavebnictví, by velkých výsledků a objevů vzhledem své vázanosti na finanční prostředky nemohla dosahovat žádné další vědní obory.

\section{Reference}

[1] Synek, M., Kislingerová, E. a kol., a. Podniková ekonomika, 5. přeprac. a dopl. vyd. Praha : C. H. Beck, 2010. 978-80-7400-336-3.

[2] Begg, D. K. H., Fischer, S. a Dornbusch, R. Economics. místo neznámé : McGraw-Hill Book Co Ltd, 1987. 007-08-4168-3

[3] Peterson, Steven J. Construction Accounting and Financial Management, 2nd ed. Upper Saddle River: Pearson Education, 2008. 013-50-1711-4

[4] Tomek, Aleš. Finanční ŕizení ve stavebním podniku. Studijní text pro předměty 126FIR a 126FIM. Praha.

[5] Schleifer, Thomas C., Sullivan, Kenneth T. a Murdough, John M. Managing the Profitable Construction Business: The Contractor's Guide to Success and Survival Strategies. New Jersey: Jon Wiley \& Sons, Inc., 2014. 978-1-118-83694-1. https://doi.org/10.1002/9781118852453

[6] Váchal, Adam. www.metrostav.cz. Metrostav posiluje v cizině. [Online] 19. 42016. http://www.metrostav.cz/cz/aktuality/aktualni_informace/detail?id=3137.

[7] Veřejný rejstřík a sbírka listin. or.justice.cz. [Online] https://or.justice.cz/ias/ui/vypis-slfirma?subjektld=415404.

[8] Skočdopole, Petr. www.motejlekskocdopole.com. Dozvuky islandského tunelu od Metrostavu: žaloba a nedořešená ztráta. [Online] 6. Září 2012. https://www.motejlekskocdopole.com/dozvuky-islandskehotunelu-od-metrostavu-zaloba-a-nedoresena-ztrata/.

[9] Kislingerová, Eva a a kol. Manažerské finance, 2. přepracované a doplněné vydání. Praha: C. H. Beck, 2007. 978-80-7179-903-0.

[10] www.gaap.cz. Světové účetnictví II online: Obecný úvod. www.gaap.cz. [Online] http://www.gaap.cz/cs/su-2-01/\#sdendnote1sym.

[11] Metrostav a a.s. www.metrostav.cz. Roční zprávy. [Online]. http://www.metrostav.cz/cz/ekonomicke_informace/rocni_zpravy/rz2015. 